\title{
Climate Change, Ecosystem Processes and Biological Diversity Responses in High Elevation Communities
}

\author{
Timothy R. Seastedt ${ }^{1, *}$ and Meagan F. Oldfather ${ }^{2}$ D \\ 1 Institute of Arctic and Alpine Research, University of Colorado, Boulder, CO 80303, USA \\ 2 Department of Ecology and Evolutionary Biology, University of Colorado, Boulder, CO 80303, USA; \\ Meagan.Oldfather@Colorado.edu \\ * Correspondence: timothy.seastedt@colorado.edu
}

Citation: Seastedt, T.R.; Oldfather, M.F. Climate Change, Ecosystem Processes and Biological Diversity Responses in High Elevation Communities. Climate 2021, 9, 87. https://doi.org/10.3390/cli9050087

Academic Editor: Forrest M. Hoffman

Received: 1 April 2021

Accepted: 17 May 2021

Published: 19 May 2021

Publisher's Note: MDPI stays neutral with regard to jurisdictional claims in published maps and institutional affiliations.

Copyright: (c) 2021 by the authors. Licensee MDPI, Basel, Switzerland. This article is an open access article distributed under the terms and conditions of the Creative Commons Attribution (CC BY) license (https:// creativecommons.org/licenses/by/ $4.0 /)$.
Abstract: The populations, species, and communities in high elevation mountainous regions at or above tree line are being impacted by the changing climate. Mountain systems have been recognized as both resilient and extremely threatened by climate change, requiring a more nuanced understanding of potential trajectories of the biotic communities. For high elevation systems in particular, we need to consider how the interactions among climate drivers and topography currently structure the diversity, species composition, and life-history strategies of these communities. Further, predicting biotic responses to changing climate requires knowledge of intra- and inter-specific climate associations within the context of topographically heterogenous landscapes. Changes in temperature, snow, and rain characteristics at regional scales are amplified or attenuated by slope, aspect, and wind patterns occurring at local scales that are often under a hectare or even a meter in extent. Community assemblages are structured by the soil moisture and growing season duration at these local sites, and directional climate change has the potential to alter these two drivers together, independently, or in opposition to one another due to local, intervening variables. Changes threaten species whose water and growing season duration requirements are locally extirpated or species who may be outcompeted by nearby faster-growing, warmer/drier adapted species. However, barring non-analogue climate conditions, species may also be able to more easily track required resource regimes in topographically heterogenous landscapes. New species arrivals composed of competitors, predators and pathogens can further mediate the direct impacts of the changing climate. Plants are moving uphill, demonstrating primary succession with the emergence of new habitats from snow and rock, but these shifts are constrained over the short term by soil limitations and microbes and ultimately by the lack of colonizable terrestrial surfaces. Meanwhile, both subalpine herbaceous and woody species pose threats to more cold-adapted species. Overall, the multiple interacting direct and indirect effects of the changing climate on high elevation systems may lead to multiple potential trajectories for these systems.

Keywords: alpine; elevation; phenology; snowpack; subalpine; traits; tree line; vegetation

\section{Introduction}

Research on factors controlling the composition of the alpine tundra and how these factors will be shaped by a changing climate has increased exponentially over recent decades [1,2]. Most simply, if high mountainous communities can be viewed as islands above subalpine forests, then warming can be thought of as analogous to sea level rise. The area available for species decreases, and, accepting the reality of species-area relationships, then species are threatened and overall numbers are expected to decline (e.g., [3]). Many mountain biotic communities may uniquely be forced into extinction with "nowhere to go". High elevation systems found in regions experiencing the most rapid heating are arguably the most at risk. This would include alpine tundra found at high latitude areas such as those in mountainous regions of the boreal forest [4,5] and those at the highest elevations 
(due to elevation-dependent warming) [6]. It is concerning that the species at the highest latitudes and elevations have both the highest climate exposure and are most at risk due the lack of suitable conditions in the future [7]. Certain alpine regions with higher number of endemic species or particular topographic features may also be especially vulnerable to changing climate conditions [8,9]. However, there is also some evidence countering this notion of all high elevation systems as severely threatened. Topographic heterogeneity of mountainous regions may buffer the direct effects of climate change [10-12]. Further, in some cases, area actually increases with elevation in mountains [13]. When assessing the overall threat of mountain communities from a changing climate, species interactions are also crucial to consider [14]; these interactions may play a large role in determining local persistence across heterogenous landscapes $[11,15,16]$.

Alpine zones occupy about $3 \%$ of the terrestrial surface of the earth $[17,18]$, and these often spectacular landscapes have been or will be impacted by the changing climate. Among recent reviews, Malaneson et al. [19] describes this impact as complex, i.e., these lands are "uncertain sentinels" with respect to species change and extirpations due to climate change. Most authors describe the biotic composition of these systems as sensitive and responsive to change [20]. The reasons for this vulnerability include: (a) evidence for more rapid warming at higher elevation than at lower elevation sites, and hence a more rapid rate of change, (b) the absence of adequate climate refugia, i.e., the absence of sites that mimic current climatic regimes, and (c) the threat of many "better adapted competitors" headed upslope to follow warming trends and that are capable of replacing extant species. Further, elevational gradients produce steep climatic gradients; thus, preferred thermal regimes for species tend to be limited in area. Predicting climate impacts on biological diversity is confounded, however, due to the individual isolation of high elevation systems in conjunction with those regional and local contingencies that influence the warming impacts on community structure and composition [18]. We are faced with the challenge that each mountain range contains potentially unique physical and biological components that will create unique scenarios with response to this warming.

Our focus here is on the fate of the species at and above tree line with an emphasis on what we believe will be the largest changes in the next few decades. We have used the extensive and intensive research and monitoring results from the Niwot Ridge of Colorado, a site with extensive climate and biological diversity records [21] (Figure 1), supplemented with recent findings and syntheses from elsewhere, to guide conceptual frameworks. We believe the Niwot Ridge studies provide a model system for many temperate and boreal high elevation landscapes, but we also acknowledge a North American bias in our findings. Extensive research on climate change for high elevation systems is ongoing across much of the planet (e.g., [2,22-24]) and those studies outside of North America incorporate a stronger socio-economic dimension in legacy effects and analyses of high elevation change. Regardless, our mission is to show that the potential changes in these systems, particularly those still containing glaciers, snowfields and permafrost, hold large consequences for all organisms both within and below these high elevation systems [25]. 


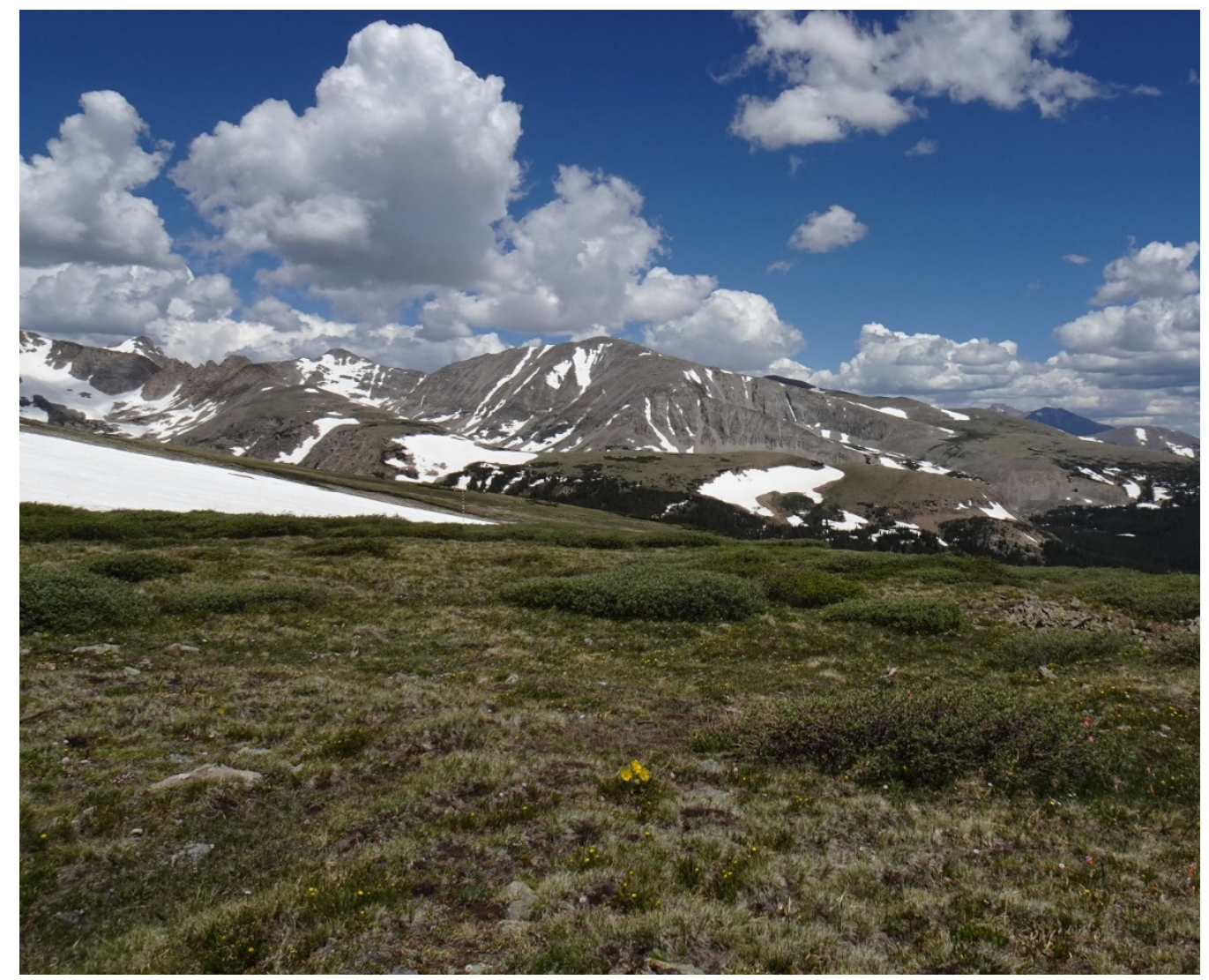

Figure 1. Typical alpine tundra found at Niwot Ridge (ca 3500 m.a.s.l., $40^{\circ} 3^{\prime} \mathrm{N}$ Lat., $105^{\circ} 35^{\prime} \mathrm{W}$ Long). The dry meadow in the foreground has been snow-free for nearly a month, while snowbed communities and some of the moist meadows have yet to emerge from the snow. Willow (here Salix glauca and S. planifolia) has increased exponentially at this site in recent decades ([26]; photo by C. M. Tate).

While we emphasize terrestrial systems in this review, climate effects may be even more amplified for high elevation aquatic communities for multiple reasons, including changes in both amounts and seasonality of streamflow and relatively larger changes to the chemistry of lakes and streams. Rapid increase in stream temperatures due to current warming (in addition to the temperature and chemistry changes due to glacier, snowfield and permafrost meltwaters initially increasing and then decreasing) will have wide-ranging impacts [27] and are thought to be particularly stressful to invertebrates in these systems [28]. The reduction in snow cover and ice controlling the productivity and species composition of alpine lakes is at least as significant as that occurring on land. Using a 36-year data set (1983-2018), Christianson et al. demonstrated that open water duration of alpine lakes at $40^{\circ} \mathrm{N}$ lat. had increased about 2.5 times faster than that observed for 215 Northern Hemisphere lakes, and the phytoplankton community composition is responding [29-31]. Mountain systems are the water towers of the world [32,33] and the fate of the high elevation communities will impact the quality and quantity of those water resources and the biota contained therein in addition to impacting downstream water users.

\section{Identifying and Quantifying the Components of Climate Change for High Elevation Species}

Our focus here is on the traditional metrics of climate seen through the lens of community ecologists, i.e., the temperature and moisture regimes experienced by a species within a defined area. This acknowledges the fact that species vulnerability to climate have individualistic, evolutionary dimensions [34], and that mountainous regions are incredibly difficult to define from a climatological standpoint at timescales relevant to 
long-lived alpine species. Extreme events such as drought, floods, and windstorms are important factors, but without a sufficient length of time in the database to define these, we cannot identify these as climate change components with high certainty. That said, there is strong evidence for increasing drought in some mountainous regions [35]. Similarly, fire in high elevation areas is emerging as a variable influenced by climate change. In contrast to drivers whose effects are similar or increased with elevation, studies suggest that increasing concentrations of $\mathrm{CO}_{2}$ does not influence herbaceous alpine species [36], likely because water, light, or soil nutrients are already limiting growth.

The temperature gradient (lapse rate) for high elevation systems averages about $6.5^{\circ} \mathrm{C}$ for every $1000 \mathrm{~m}$ in elevation [37] or about $154 \mathrm{~m}$ per $1^{\circ} \mathrm{C}$ change. At local scales, cold air drainage can reverse temperature gradients for periods of time [38]. For example, at Niwot Ridge, the annual average lapse rate was $7.3^{\circ} \mathrm{C} / \mathrm{km}$ for the period $1952-2010$, with a maximum lapse rate of $10.6^{\circ} \mathrm{C} / \mathrm{km}$ and a minimum lapse rate of $4.0^{\circ} \mathrm{C} / \mathrm{km}(\mathrm{T}$. Kittel, Univ. Colorado, Unpublished). Precipitation, often maximized at the highest elevations, can also exhibit inversions [39]. However, the data on precipitation are also confounded by biases in collections due to the often strong wind effects [40]. The current changes in temperatures in the mountains tend to follow the trends of the regional climate [4], although higher elevations may be at more risk for warmer and drier conditions [6,41]. It is possible, albeit highly speculative, to estimate species risk as a function of their current elevation range and estimates of warming. Thus, if the climate has warmed by $2{ }^{\circ} \mathrm{C}$, the required adjustment of a species whose climatic requirements have not changed would be to move up in elevation by about $300 \mathrm{~m}$. Over the last century, mammals from montane areas have moved up in average elevation by about $350 \mathrm{~m}$ based on records obtained from field collections [42]. These distributional shifts approximately align with the increase in temperature $\left(\sim 2{ }^{\circ} \mathrm{C}\right)$ since museum collections began. Further exploration of this approach might be able to address the question: "How long do we have before species are driven off the tops of the mountains?". For example, if alpine zones in our area begin around $3300 \mathrm{~m}$ and essentially run out of habitat at $4000 \mathrm{~m}$, then those organisms whose preferred elevation is at $3300 \mathrm{~m}$ have about $4.5^{\circ} \mathrm{C}$ of warming to exploit before these organisms reach elevational limits. Species who have preferred climate zones midway or higher up in the alpine have a smaller level of temperature change that could be compensated for by moving upslope.

The main fallacy of this logic involves the assumption that other climate-related variables will also change proportionately with increasing temperatures (e.g., freeze-thaw frequencies, growing season timing and duration, etc.). Further, interactions between these climate variables can drive individualist biogeographic responses of species and novel climate conditions $[12,43,44]$. With increased speed of snowmelt, capable of creating both drier and wetter plant communities, these combinations of warming-wetting and warming-drying will produce non-analogue plant communities [45]. In the high alpine areas in particular, the presence and abundance of snow has as a transformative effect and its current and future impacts for how mountain species respond to climate change need to be considered. The high albedo (reflectivity) of snow can prevent surface warming and keep snow-covered sites cooler during the day and warmer at night. Snow cover can also modulate the temperatures plants are exposed to in the spring and autumn $[17,46]$. There has been a documented broad-scale decrease in snow-pack in the Western US [47], and the rate at which this is occurring is also increasing in a majority of sites measured over the last 40 years [48]. At Niwot Ridge, precipitation has increased over the last 70 years, largely as snow, and this is correlated with a slowing of peak summer warming relative to subalpine measurements $[49,50]$. Even so, growing season length is increasing at this site [51]. The presence and amount of snow can be seen as a control of growing season duration, soil moisture, and the seasonality of soil temperature dynamics. While this variable is often the key focus in plant studies, snow dynamics also directly impact habitat use by consumers such as alpine gophers [52] or pika [53], which in turn have potentially large grazing impacts. 
An added complication to quantifying the consequences of climate change for mountainous regions is that land use change has, in many instances, accompanied climate change. Herbaceous systems such as alpine and subalpine meadows can be strongly impacted by grazing, and grazing legacies may be superimposed over climate effects [54,55]. Grazing has the potential to alter both plant competition and soil characteristics within a fixed climatic region and is therefore fundamental to understanding species and community responses to warming. Further, grazing offers potential mitigation to warming in at least some alpine systems [56]. Here, we assume that at least some grazing impacts are imbedded in North American responses, but grazing impacts are perhaps not as intensive or pervasive as on other continents.

\section{Patterns of Species Richness and Vulnerability to Climate Change}

The greatest percentage of land area occupied by alpine zones is found around $40^{\circ} \mathrm{N}$ latitude, with the boreal/subarctic zone having the second largest amount of alpine tundra [57]. Species richness and genetic diversity of alpine species is perhaps best known from Europe (e.g., [58,59]. As noted by the authors of these works, regional species numbers and the relative numbers of endemic alpine species vary across that region. Within a montane area, there are underlying topographic patterns in species richness, with most species occurring at intermediate levels within the alpine [60]. Thus, species richness changes with respect to a directional forcing depending upon the reference point. Upper regions of the alpine, for example, may experience increases in alpine species, whereas lower regions may experience reductions due to encroachment of species from below. When an alpine region is composed largely of a single elevation, then the local heterogeneity of the landscape controls both local patterns of species richness and community composition [61,62]. As mentioned above, Rumpf et al. [6] found European alpine species richness at the highest elevation to be most at risk, an observation supported by local findings at our site [63]. In terms of number of species added or lost, the largest changes may occur at the subalpinealpine interface as a suite of pre-adapted subalpine species are present to outcompete more cold-adapted and potentially slower-growing species $[16,64]$.

While documented changes should invoke concern due to the ongoing loss of available habitats, other authors have found evidence of persistence of cold region flora over past periods of rapid climate change [65]. Over short timeframes of one to two decades, species richness of alpine systems can increase [66-69], but species losses have also been observed $[63,64,70]$. The change in alpine species has also been shown to vary across broadscale precipitation gradients, with species losses more likely in more arid climates [71,72]. Further, responses to climate change will be species-specific and dependent on species phylogeny and life-history strategy. Dicots as opposed to monocots have shown much larger reductions in population density at their southern range limits in the Rockies over the last 10-25 years [73]. Herbaceous perennial plants (the common lifeform in alpine areas) are also much more sensitive to temperature and precipitation anomalies when they have shorter generations times [74]. Therefore, some have argued that species responses to climate change will contain multiple lags ("dispersal, establishment, and extinction lags") due to longevity and the slow growth of many alpine species. Species abundances may shift prior to species gains or losses, begging the question if our current observed responses are transitory $[7,16]$. These lags may explain why we first see gains in diversity despite predicted loss of diversity with climate change, as species are not locally extirpated by climate directly, but by increased competition or loss of facilitation. Therefore, alpine species at lower elevations may experience the largest threat from subalpine competitors moving into their former habitats [75].

Modeling exercises that extend beyond a few decades provide a scenario based upon known facts and interactions, both of which can change over time. While climate and elevation provides a uniform gradient, which organizes the subalpine, alpine, and nival systems, local and regional factors including photoperiod, soil moisture, wind effects, soil conditions and human land use legacies, have also sculpted the current patterns of 
biodiversity of the alpine area (Figure 2; [76]). All of these factors (which are difficult to include in general model predictions) will continue to interact with the changing climate to shape species distributions [77] and can generate novel or hybrid ecosystems. For example, following the rapid climate change at the end of the Pleistocene, novel, and now absent, communities assembled [78]. Further, plant species dependent upon pollinators may have additional issues as pollinators respond to the changing climate at different rates and scales than the plants they pollinate [79]. Thus, predictions from models not exploring multiple scenarios are arguably blunt tools but essential in informing the range of actions needed to mitigate the various scenarios. Given that caveat, the predicted future for alpine species looks grim. Dullinger et al. [80] and Engler et al. [72] found averages approaching 50\% range reductions by 2100. In a modeling exercise by Niskanen et al. [81], species richness of a European mountain flora is predicted to decrease by $15-47 \%$ per $1 \mathrm{~km}^{2}$ cell by the year 2100. Again, using the simple relationship known for species richness and area of habitat [3], this has large consequences. A note of optimism, the Niskanen model indicated that alpine flora could find suitable habitat at higher latitudes.

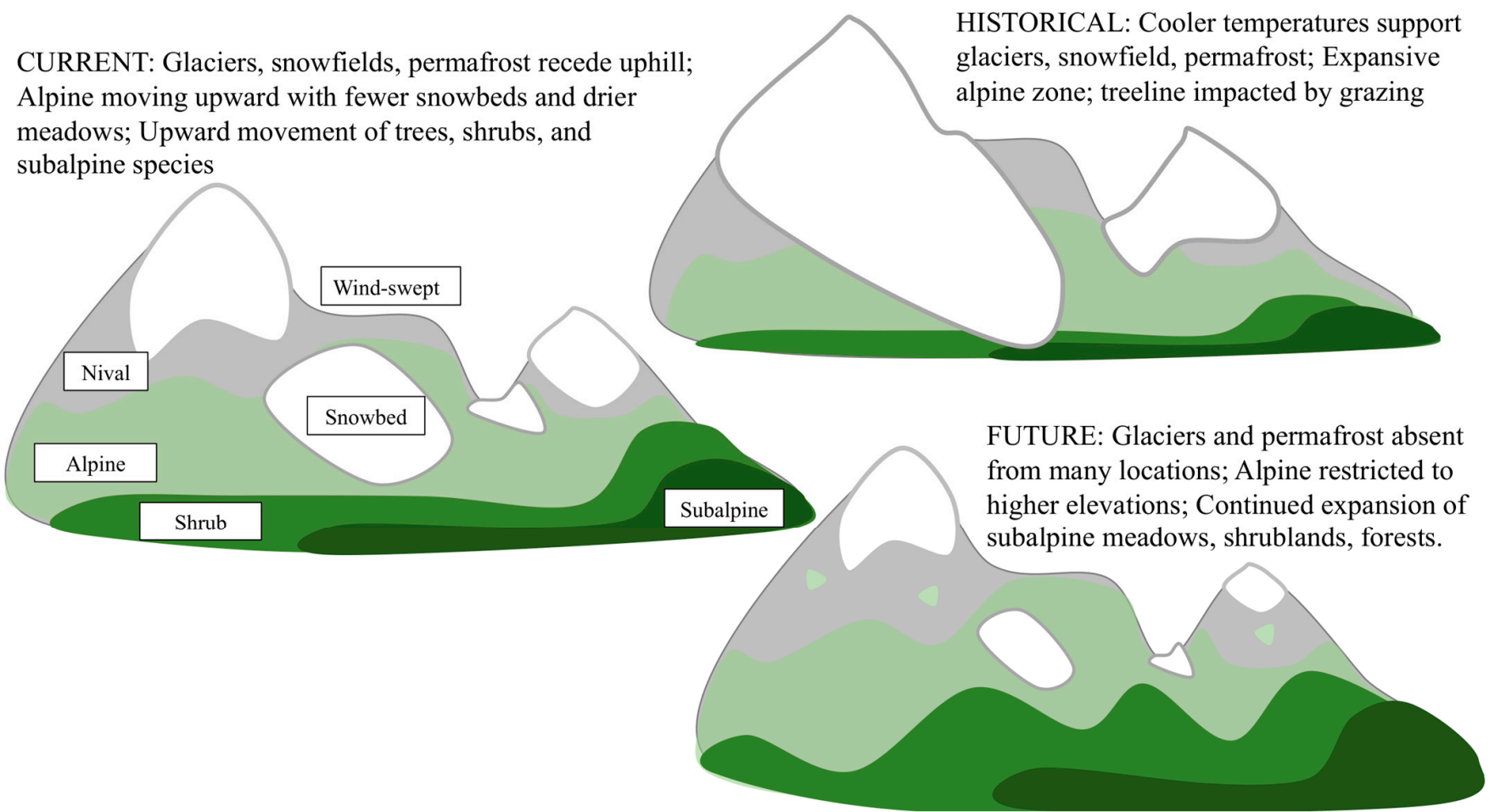

Figure 2. Directional warming of high elevation systems influences species whose life cycles have been largely controlled by amount of snow and snow duration. Historically, windswept surfaces remained snow-free most of the year, whereas snow redeposited into protected areas and at the tree line can remain snow-covered for much or even all of the growing season. Heating and seasonality of heating and light input to soil therefore occur along an elevational gradient and along the reduced-snow gradient, which can be separated to elevation relationships. The historical legacies (human use, grazing, etc.) also impose additional factors that affect vegetation dynamics.

\section{How Warming Will Change Local Plant Community Composition}

The alpine consists of a continuum of plant communities structured largely by snow amounts and duration, with topography and wind generating this local redistribution of snow $[17,82]$. About 250 vascular plant species can be found above the tree line at Niwot Ridge Colorado, and this vegetation demonstrates a well-defined landscape gradient of species richness. As at other sites, species richness declines as one moves from mid-range in the alpine towards the tree line, and as one ascends to uppermost peaks. Patterns found in the five herbaceous communities (fellfield, dry meadow, moist meadow, wet 
meadow, and snowbed communities) also produce distinctive patterns in species richness and diversity [83]. A sixth potential community type, the shrub tundra, often exhibits the lowest local species richness [70]. Slope and aspect can reproduce these gradients at very local scales.

The wind-scoured fellfields are devoid of snow most of the year, and vegetation in these areas largely relies on late spring snowstorms and on summer precipitation. At Niwot Ridge, this means the soils at these sites receive perhaps $20 \%$ of annual precipitation, with the redistributed snow subsidizing late-melting snow meadows, snowbed communities, and snowfields often failing to melt out in any particular year. With greater warming, all alpine sites should receive more rain and less snow. This pattern means that snowbed communities may experience warming, drying (less snow from windblown sites), and a longer growing season, while other communities may receive more plant-available water along with the warming and longer growing season. The combined changes in temperature and moisture will favor some species and perhaps some lifeforms over others. For example, a 4 yr warming experiment at Niwot Ridge demonstrated that graminoids could increase while forbs and cushion plants would decrease in cover if additional water was not added $[84,85]$. One might expect that cushion plants, perhaps the best adapted species to persist in the wind-scoured fellfields, would not be outcompeted by other species, but temperatures may supervene in this relationship. With changing resource relationships, facilitation may turn into competition and vice versa [86]. Hence, as resource limitations change from water to nutrient to light limitations (and co-limitations thereof), one should expect winners and losers as these differing resource regimes found across the alpine landscape are altered by warming.

For the coming decades, enhanced snowmelt and reduced snow cover should support a larger area of the more mesic and dry alpine meadow communities. The extension of the snow-free period is a near certainty, and if this is accompanied by more plant-available water, these systems may become more productive. Exactly how this affects nutrient availability is speculative, but changes in nutrient availability will alter plant community composition [87-89]. More belowground production adds soil carbon and may offset some of the carbon loss anticipated from enhanced decomposition [90]. This carbon loss is to be expected, with directional warming of soils containing moderately high amounts of soil organic matter [91].

These types of dynamics discussed above will play out over very fine-spatial scales in the alpine area. High elevation ecosystems are more heterogeneous in terms of local climate conditions than perhaps all other terrestrial ecosystems of comparable areas, a fact emphasized decades ago by Johnson and Billings [61]. The heterogeneity of high elevation systems means that many different microclimates and microhabitats exist over small areas and would seem to offer species local refugia to climate change [92,93], at least over decadal periods. There are in fact multiple ways in which the topographic heterogeneity of mountainous areas may buffer alpine communities from the direct effects of climate change. Heterogenous landscapes often have higher local species diversity, making it more likely a local species may thrive in the new conditions [94]. Topographic complexity has also been shown to reduce climate-induced local extirpations [10] and landscape heterogeneity allows species to more easily track suitable conditions [11,95]. Species living in mountain landscapes may also be more adapted to cope with changing climate in some ways (wider niches, reliance on long-lived adults less sensitive to annual variability for population persistence), but not in other ways (exposure to nearby competitors, lower populations sizes with smaller areas) $[11,15]$. However, climate change may also alter the steepness of the topographic heterogeneity through non-linear responses across geographic gradients such as elevation-dependent warming [6]. There is concern that non-linear climate responses and threshold behaviors of populations and communities may result in high elevation landscapes becoming abiotically and biotically homogenized. This could reduce the potential buffering effect of topographic heterogeneity, increasing the potential threat of climate change. There has been evidence that past climate change has 
homogenized the phylogenetic diversity of European plants [96], but for current climate change it is not yet clear if increasing spatial homogenizing or temporal synchrony will have a large role in mountain species responses to changing climate [97].

\section{Herbaceous Species Moving Uphill}

If warming creates a "new habitat" at a higher elevation or from melting snowfields, we should expect adapted species to colonize these areas. Insights of this process come from studies of primary succession following glacier retreats [98]. However, glaciers tend to melt out initially at fairly low elevations. The colonization of rock and snow by vegetation species of high elevation areas may be under a different set of environmental constraints that limit both the rate and occupancy by alpine plant species.

There is strong evidence for uphill movement of herbaceous species (Figure 3) [51,63,66,99-101], with vegetation colonizing heights not obtained since before the Pleistocene. This migration solution to directional warming can work only if such high elevation areas exist, and, equally important, if there are suitable substrates for the species [102,103]. One has to believe that soil development of steep slopes in these cold and often windswept areas will lag behind the warming driver, and, given soil limitations, this will select the subset of vegetation adapted to "fellfield-like" characteristics. For example, species that have ability to live in scree fields (e.g., due to having contractile roots) may be more able to expand into higher elevations and avoid being outcompeted by species that are more adapted to the climate but not the microhabitat conditions [103]. While this includes a large number of alpine species, life may become difficult for the more mesic soil-loving sedges that dominate much of the alpine area. Wind scour, a pervasive factor in species presence and abundance in many alpine areas, is likely to only increase with elevation, regardless of warming effects on this variable, so wind scour and soil limitations may limit upward migrations into otherwise available habitats.

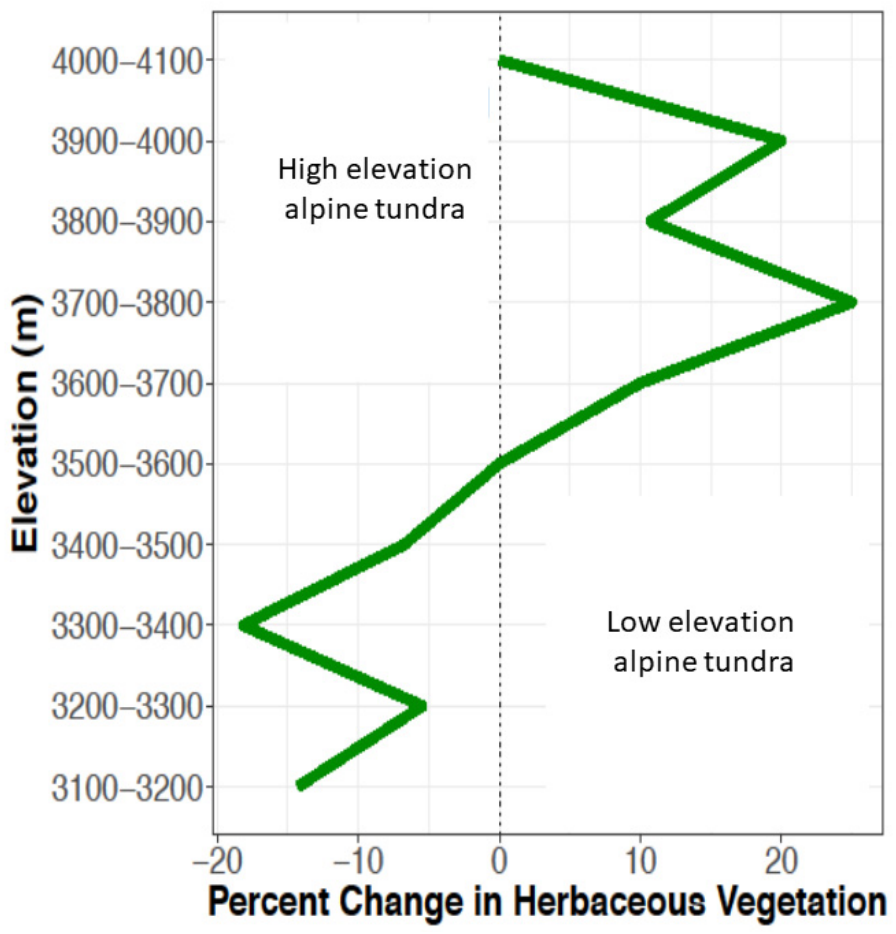

Upward migration limited by lack of adequate substrates

Inflection point: point of Within-herbaceous community replacements

Shrub invasion: inter-lifeform competition

Figure 3. Vegetation uphill movements, 1972-2008. Viewed from the perspective of relative herbaceous vegetation cover change at Niwot Ridge, Colorado; shrub invasion reduces herbaceous species cover at lower elevations. Midway up the mountain, community change within herbaceous communities dominated, while at uppermost elevations herbaceous vegetation colonization of what was largely bare rock and scree habitats is ongoing (redrawn from De Mesquita et al. [51]). 


\section{Shrublandification and Tree Encroachment}

Woody species encroachment occurs in most high elevation systems. Trees and shrubs are moving uphill in the majority of mountain systems [51,104,105]. Bowling et al. [106] captured key points from the literature that encapsulates factors affecting change in tree line including warmer late winter temperatures, more rainfall and less snow accumulation, and earlier snowmelt. They noted that climate models expect these conditions to continue. Further, enhanced atmospheric $\mathrm{CO} 2$ concentrations appear to directly benefit trees more than herbaceous species [107-109]. While climate is arguably the main cause of this movement, the removal of ungulate grazers and termination of heavy grazing of high elevation systems likely contribute to this overall upward migration of wood species (e.g., [56]), which has not only negative impacts to select plant species but will also affect avifauna as well [110].

Tree islands and krummholz are the vanguard of forest encroachment of the alpine area. The current presence of krummholtz in the tundra was identified as a legacy effect of past climates [111] and will likely have a strong impact on tree colonization of higher elevation systems with now more benign climatic regimes. While most tree islands appear on wind-protected sites that allow the trees to grow shrub-like within the alpine landscape, some of these trees are capable of lateral movement across the alpine tundra [111]. The windward sides of these trees function as snow fences, but succumb to ice abrasion and needle death. However, these trees produce adventitious roots from branches buried in needle litter and other organic materials accumulated beneath the tree island, and therefore can grow towards the leeward even if the initial stem of the tree is killed by ice abrasion. These trees function as nurse plants to whatever can exploit the leeward side of the tree, an area made moister along with a reduced growing season by tree-generated snowdrifts. Subalpine herbaceous species are often found adjacent to and beneath these trees. Nonmoving tree islands create similar drifts and appear to also function as nurse plants to woody vegetation $[112,113]$. The result under a warming scenario appears to be woody plant expansion into what were formerly areas dominated by herbaceous areas.

At Niwot Ridge in Colorado, woody encroachment of herbaceous areas appears to be ongoing in most alpine habitats save, perhaps, the fellfields. At this site, a subset of willow species mimic cushion plants in terms of morphology and appear capable of persisting in all but the driest and most windswept of habitats. Based on a 40-year monitoring study of the six communities described at this site, the increase in cover by woody species in areas outside of those classified as shrub tundra is greatest in moist and wet herbaceous meadow habitats [70]. Similar reports have appeared elsewhere; the abundance and relative cover of shrubs are increasing $[26,114,115]$. We found only a single citation suggesting that herbaceous species were replacing shrubs [116], and in that case some unique soils and disturbance history may be influencing this response. It is of note that, should reduced snow cover lead to enhanced surface freezing events, shrubs could be harmed [117], thereby slowing shrub encroachment.

The plant architecture of shrub tundra differs substantially from that of alpine herbaceous communities. The shrubs function as wind breaks and snow fences, similar to the krummholz vegetation. A positive (amplifying) feedback loop is created when warming facilitates shrub invasion, which then facilitates the creation of moister habitats. Further, branches of shrubs emerge earlier from snow and their darkened surfaces facilitate warming and localized snowmelt. This may expand the growing season for the shrubs, thereby facilitating their presence and their encroachment of adjacent herbaceous areas. Woody encroachment will subsequently alter the soil microbial community as well as the nutrient status of the soils, influencing which understory species persist in these areas, but, once again, this will be mediated by topography.

Shifts in tree lines will also be shaped by exposure to changing temperature and moistures regimes. Lu et al. [118] found that over the last century in the Northern Hemisphere, about $89 \%$ of tree lines moved uphill, $10 \%$ remained stable, and about $1 \%$ of 143 sites were found at lower elevations. The mean upward movement was $0.35 \mathrm{~m} /$ year, slower than 
that expected from our earlier calculations or that seen for mammals. However, tree line shifts were significantly faster in subarctic than temperate regions, consistent with regional warming trends. Tree line movement may also be constrained by moisture [113]. In the subarctic regions, autumn precipitation was most important to tree line shift rates. Lu et al. [118] also reported that warmer temperatures and higher autumn precipitation in the temperate zone accelerated distributional shifts, while wetter springs reduced them. In another recent review on tree line shifts by Hanssan et al. [119], which summarized 144 tree line studies across 477 study locations, only $66 \%$ of tree lines either moved uphill or to higher latitudes. The difference in percentages of shifting tree lines reported in these two studies potentially implies that moving uphill is more likely than moving latitudinally at these timescales (cf., [120]). Regardless, the differences suggest that substantial uncertainty remains regarding the speed and spatial patterns involved in the migration process of tree lines across heterogenous landscapes.

\section{The Increasing Importance of Fire}

Recently, the mountain ranges of Colorado have experienced wildfires that have consumed subalpine forests and have succeeded in crossing the Continental Divide at elevations above the tree line. The alpine tundra did not seem much effected from these fires, but more frequent and intense fires will certainly affect woody dominance within the subalpine zone and, via seed limitation, tree encroachment of higher elevations. The lack of fuel build-up and the perennial lifeform of the alpine flora should protect these species unless, as has now occurred in the arctic, actual organic matter consumption of soils occurs. Many alpine habitats contain substantial organic matter at the soil surface. Dry organic matter and the strong winds of high elevation systems could produce what are traditionally called ground fires. We would hope this remains a very rare occurrence, as recovery post-fire would likely be very slow and potentially lead to subsequent species loss. However, continued warming increases the probability of these eventually being part of the alpine. Similar to what is now being seen at low elevation forests where regeneration of tree species is severely restricted by moisture limitation [121], these fires could function as transformative events and convert an alpine-dominated flora to subalpine herbaceous meadows.

\section{Conclusions}

High elevation communities will be strongly impacted by a changing climate. The drivers of this biotic change will be due to the direct effect of climate change through multiple interacting climate variables and indirectly climate-mediated species interactions with both of these mechanisms dependent on the fine-scale topographic gradients that universally characterize these mountain systems. The topographic realities of each range and its history will shape the trajectories of these systems in a warmer, drier, and less snowy world. High topographic heterogeneity may be able to buffer the impact of climate change both due to the current diversity in the landscape and the potential for species to track nearby climate. However, this overall effect is dependent on if there is enough space for population persistence, how species climate-affinities overlap across the landscape, and if the heterogeneity is constant over time [11,15].

From our review of the literature and our observations from our multi-decadal research program in the Colorado alpine region, we have identified areas where high elevation species may need our help fairly soon. These include:

1. High elevation systems in those areas of the planet experiencing the most rapid change;

2. Those species whose current climate regimes will no longer exist due to either shifts to non-analogue climate conditions or lack of additional habitat at the highest elevations;

3. Those species adapted to snowbed communities and short growing seasons;

4. Those species in moister habitats more vulnerable to woody species invasions. 
Subalpine species, including both herbaceous species on drier, artificially grazed, or fire-maintained habitats, and woody lifeforms on wetter, ungrazed habitats, are in the process of challenging colder/shorter growing season-adapted alpine species. Only a portion of the alpine species have possible escape routes. The rapidity of this change, and the consequences in terms of alpine species losses, will be a function of local and regional environments. Fire is likely to play a larger role in this process in at least some montane systems.

What is to be done? Inouye (2020) [79] emphasized the need to repeat historical surveys, take advantage of museum collections, and use new technology that will facilitate our understanding of how plants and pollinators are responding to the changing alpine environment. Excellent examples of this effort are available [122]. This advice can be expanded to the entire biota (e.g., McCain et al. [32]). Emphasis should be placed on sites already with existing or baseline data, as it is clear from long-term monitoring that decadal-scale changes will produce both positive (species increases) and negative (species decreases) though time. Unfortunately, the current, directional climate drives suggest that the negative outcomes are unavoidable without novel interventions. Excluding science fiction futures that would consist of species gardens in current arctic areas, temperature stabilization would seem to be the only solution if high elevation, alpine species are to persist within remnants of their existing habitats.

Continued unabated, warming at high elevation systems in temperate and boreal zones will greatly impact the distributions, interactions, and productivity of alpine areas. With a changing climate, species adapted to cold and snow may shift across topographic gradients, be locally excluded by faster-growing subalpine species, run out of suitable habitat at higher elevations, or form novel community assemblages. For the coming decades, we can now make reasonable predictions about which of the high elevation communities are at risk, with the assumption that species contained therein are at similar risk based upon known traits and bioclimatic variables. Additionally, if these communities contain habitat-restricted, endemic species, then one has to predict high extinction rates without facilitated migration. However, sufficient uncertainties remain and we argue that frequent monitoring is essential to provide the information needed for this exercise.

Author Contributions: T.R.S. and M.F.O. worked equally on this project. Both authors have read and agreed to the published version of the manuscript.

Funding: This research received no external funding.

Institutional Review Board Statement: Not Applicable.

Informed Consent Statement: Not Applicable.

Data Availability Statement: All data used for our Niwot Ridge analyses can be found through the data portal at: https:/ / nwt.lternet.edu/data-catalog (accessed on 26 April 2021).

Acknowledgments: We acknowledge that our own research has been performed on the ancestral lands of the Southern Arapaho, Cheyenne, and Ute peoples and more recently been managed by the USFS and the City of Boulder. We thank our colleagues of the Niwot Long-Term Ecological Research (LTER) program for providing inputs to this effort and in particular to Sarah Elmendorf, C. B. de Mesquita and Tim Kittel for insights and suggestions. The NWT LTER program has been funded by the National Science Foundation continuously since 1980, with the most recent grant (DEB- 1637686) contributing to this effort.

Conflicts of Interest: The authors declare no conflict of interest.

\section{References}

1. Verrall, B.; Pickering, C.M. Alpine Vegetation in the Context of Climate Change: A Global Review of Past Research and Future Directions. Sci. Total Environ. 2020, 748, 141344. [CrossRef] [PubMed]

2. Catalan, J.; Ninot, J.M.; Aniz, M.M. (Eds.) High Mountain Conservation in a Changing World; Advances in Global Change Research; Springer International Publishing: Cham, Switzerland, 2017; Volume 62, ISBN 978-3-319-55981-0.

3. Wilson, J.B.; Peet, R.K.; Dengler, J.; Pärtel, M. Plant Species Richness: The World Records. J. Veg. Sci. 2012, 23, 796-802. [CrossRef] 
4. Nogués-Bravo, D.; Araújo, M.B.; Errea, M.P.; Martínez-Rica, J.P. Exposure of Global Mountain Systems to Climate Warming during the 21st Century. Glob. Environ. Chang. 2007, 17, 420-428. [CrossRef]

5. Grimm, N.B.; Chapin, F.S.; Bierwagen, B.; Gonzalez, P.; Groffman, P.M.; Luo, Y.; Melton, F.; Nadelhoffer, K.; Pairis, A.; Raymond, P.A.; et al. The Impacts of Climate Change on Ecosystem Structure and Function. Front. Ecol. Environ. 2013, 11, 474-482. [CrossRef]

6. Mountain Research Initiative EDW Working Group Elevation-Dependent Warming in Mountain Regions of the World. Nat. Clim. Chang. 2015, 5, 424-430. [CrossRef]

7. Rumpf, S.B.; Hülber, K.; Klonner, G.; Moser, D.; Schütz, M.; Wessely, J.; Willner, W.; Zimmermann, N.E.; Dullinger, S. Range Dynamics of Mountain Plants Decrease with Elevation. Proc. Natl. Acad. Sci. USA 2018, 115, 1848-1853. [CrossRef]

8. Wershow, S.T.; DeChaine, E.G. Retreat to Refugia: Severe Habitat Contraction Projected for Endemic Alpine Plants of the Olympic Peninsula. Am. J. Bot. 2018, 105, 760-778. [CrossRef]

9. Dolezal, J.; Jandova, V.; Macek, M.; Mudrak, O.; Altman, J.; Schweingruber, F.H.; Liancourt, P. Climate Warming Drives Himalayan Alpine Plant Growth and Recruitment Dynamics. J. Ecol. 2021, 109, 179-190. [CrossRef]

10. Suggitt, A.J.; Wilson, R.J.; Isaac, N.J.B.; Beale, C.M.; Auffret, A.G.; August, T.; Bennie, J.J.; Crick, H.Q.P.; Duffield, S.; Fox, R.; et al. Extinction Risk from Climate Change Is Reduced by Microclimatic Buffering. Nat. Clim. Chang. 2018, 8, 713-717. [CrossRef]

11. Graae, B.J.; Vandvik, V.; Armbruster, W.S.; Eiserhardt, W.L.; Svenning, J.-C.; Hylander, K.; Ehrlén, J.; Speed, J.D.M.; Klanderud, K.; Bråthen, K.A.; et al. Stay or Go-How Topographic Complexity Influences Alpine Plant Population and Community Responses to Climate Change. Perspect. Plant Ecol. Evol. Syst. 2018, 30, 41-50. [CrossRef]

12. Oldfather, M.F.; Kling, M.M.; Sheth, S.N.; Emery, N.C.; Ackerly, D.D. Range Edges in Heterogeneous Landscapes: Integrating Geographic Scale and Climate Complexity into Range Dynamics. Glob. Chang. Biol. 2020, 26, 1055-1067. [CrossRef]

13. Elsen, P.R.; Tingley, M.W. Global Mountain Topography and the Fate of Montane Species under Climate Change. Nat. Clim. Chang. 2015, 5, 772-776. [CrossRef]

14. Alexander, J.M.; Diez, J.M.; Levine, J.M. Novel Competitors Shape Species' Responses to Climate Change. Nature 2015, 525, 515-518. [CrossRef]

15. Ackerly, D.D.; Kling, M.M.; Clark, M.L.; Papper, P.; Oldfather, M.F.; Flint, A.L.; Flint, L.E. Topoclimates, Refugia, and Biotic Responses to Climate Change. Front. Ecol. Environ. 2020, 18, 288-297. [CrossRef]

16. Alexander, J.M.; Chalmandrier, L.; Lenoir, J.; Burgess, T.I.; Essl, F.; Haider, S.; Kueffer, C.; McDougall, K.; Milbau, A.; Nuñez, M.A.; et al. Lags in the Response of Mountain Plant Communities to Climate Change. Glob. Chang. Biol. 2018, 24, 563-579. [CrossRef] [PubMed]

17. Körner, C. Alpine Plant Life: Functional Plant Ecology of High Mountain Ecosystems; Springer: Berlin/Heidelberg, Germany, 2003; ISBN 978-3-540-00347-2.

18. Testolin, R.; Attorre, F.; Jiménez-Alfaro, B. Global Distribution and Bioclimatic Characterization of Alpine Biomes. Ecography 2020, 43, 779-788. [CrossRef]

19. Malanson, G.P.; Resler, L.M.; Butler, D.R.; Fagre, D.B. Mountain Plant Communities: Uncertain Sentinels? Prog. Phys. Geogr. Earth Environ. 2019, 43, 521-543. [CrossRef]

20. Grabherr, G.; Gottfried, M.; Pauli, H. Climate Change Impacts in Alpine Environments. Geogr. Compass 2010, 4, 1133-1153. [CrossRef]

21. Leopold, M.; Lewis, G.; Dethier, D.; Caine, N.; Williams, M.W. Cryosphere: Ice on Niwot Ridge and in the Green Lakes Valley, Colorado Front Range. Plant Ecol. Divers. 2015, 8, 625-638. [CrossRef]

22. Wang, H.; Liu, H.; Cao, G.; Ma, Z.; Li, Y.; Zhang, F.; Zhao, X.; Zhao, X.; Jiang, L.; Sanders, N.J.; et al. Alpine Grassland Plants Grow Earlier and Faster but Biomass Remains Unchanged over 35 Years of Climate Change. Ecol. Lett. 2020, 23, 701-710. [CrossRef]

23. Ozturk, M. (Ed.) Climate Change Impacts on High-Altitude Ecosystems; Springer: Berlin, Germany, 2015; ISBN 978-3-319-12858-0.

24. Llambí, L.D.; Rada, F. Ecological Research in the Tropical Alpine Ecosystems of the Venezuelan Páramo: Past, Present and Future. Plant Ecol. Divers. 2019, 12, 519-538. [CrossRef]

25. Beniston, M.; Farinotti, D.; Stoffel, M.; Andreassen, L.M.; Coppola, E.; Eckert, N.; Fantini, A.; Giacona, F.; Hauck, C.; Huss, M.; et al. The European Mountain Cryosphere: A Review of Its Current State, Trends, and Future Challenges. Cryosphere 2018, 12, 759-794. [CrossRef]

26. Formica, A.; Farrer, E.C.; Ashton, I.W.; Suding, K.N. Shrub Expansion Over the Past 62 Years in Rocky Mountain Alpine Tundra: Possible Causes and Consequences. Arct. Antarct. Alp. Res. 2014, 46, 616-631. [CrossRef]

27. Crawford, J.T.; Hinckley, E.S.; Neff, J.C. Long-Term Trends in Acid Precipitation and Watershed Elemental Export From an Alpine Catchment of the Colorado Rocky Mountains, USA. J. Geophys. Res. Biogeosci. 2020, 125. [CrossRef]

28. Giersch, J.J.; Hotaling, S.; Kovach, R.P.; Jones, L.A.; Muhlfeld, C.C. Climate-Induced Glacier and Snow Loss Imperils Alpine Stream Insects. Glob. Chang. Biol. 2017, 23, 2577-2589. [CrossRef]

29. Oleksy, I.A.; Beck, W.S.; Lammers, R.W.; Steger, C.E.; Wilson, C.; Christianson, K.; Vincent, K.; Johnson, G.; Johnson, P.T.J.; Baron, J.S. The Role of Warm, Dry Summers and Variation in Snowpack on Phytoplankton Dynamics in Mountain Lakes. Ecology 2020, ecy.3132. [CrossRef]

30. Oleksy, I.A.; Baron, J.S.; Beck, W.S. Nutrients and Warming Alter Mountain Lake Benthic Algal Structure and Function. Freshw. Sci. 2021, 40, 88-102. [CrossRef] 
31. Loria, K.A.; McKnight, D.; Ragar, D.M.; Johnson, P.T.J. The Life Aquatic in High Relief: Shifts in the Physical and Biological Characteristics of Alpine Lakes along an Elevation Gradient in the Rocky Mountains, USA. Aquat. Sci. 2020, 82, 11. [CrossRef]

32. Messerli, B.; Viviroli, D.; Weingartner, R. Mountains of the World: Vulnerable Water Towers for the 21st Century. Ambio 2004, 13, 29-34. [CrossRef]

33. Bandyopadhyay, J. Water Towers of the World. People Planet 1996, 5, 14-16.

34. Moritz, C.; Agudo, R. The Future of Species Under Climate Change: Resilience or Decline? Science 2013, 341, 504-508. [CrossRef]

35. Tramblay, Y.; Llasat, M.C.; Randin, C.; Coppola, E. Climate Change Impacts on Water Resources in the Mediterranean. Reg. Environ. Chang. 2020, 20, 83. [CrossRef]

36. Inauen, N.; Körner, C.; Hiltbrunner, E. No Growth Stimulation by CO2 Enrichment in Alpine Glacier Forefield Plants. Glob. Chang. Biol. 2012, 18, 985-999. [CrossRef]

37. Diaz, H.F.; Bradley, R.S. Temperature Variation during the Last Century at High Elevations Sites. Clim. Chang. 1997, 36, 253-279. [CrossRef]

38. Hiebl, J.; Schöner, W. Temperature Inversions in Austria in a Warming Climate-Changes in Space and Time. metz 2018, 27, 309-323. [CrossRef]

39. Collados-Lara, A.-J.; Pardo-Igúzquiza, E.; Pulido-Velazquez, D.; Jiménez-Sánchez, J. Precipitation Fields in an Alpine Mediterranean Catchment: Inversion of Precipitation Gradient with Elevation or Undercatch of Snowfall? Int. J. Clim. 2018, 38, 3565-3578. [CrossRef]

40. Sevruk, B.; Ondrás, M.; Chvíla, B. The WMO Precipitation Measurement Intercomparisons. Atmos. Res. 2009, 92, 376-380. [CrossRef]

41. McCullough, I.M.; Davis, F.W.; Dingman, J.R.; Flint, L.E.; Flint, A.L.; Serra-Diaz, J.M.; Syphard, A.D.; Moritz, M.A.; Hannah, L.; Franklin, J. High and Dry: High Elevations Disproportionately Exposed to Regional Climate Change in Mediterranean-Climate Landscapes. Landsc. Ecol. 2016, 31, 1063-1075. [CrossRef]

42. McCain, C.M.; King, S.R.B.; Szewczyk, T.M. Unusually Large Upward Shifts in Cold-adapted, Montane Mammals as Temperature Warms. Ecology 2021. [CrossRef]

43. Rapacciuolo, G.; Maher, S.P.; Schneider, A.C.; Hammond, T.T.; Jabis, M.D.; Walsh, R.E.; Iknayan, K.J.; Walden, G.K.; Oldfather, M.F.; Ackerly, D.D.; et al. Beyond a Warming Fingerprint: Individualistic Biogeographic Responses to Heterogeneous Climate Change in California. Glob. Chang. Biol. 2014, 20, 2841-2855. [CrossRef]

44. Harsch, M.A.; HilleRisLambers, J. Climate Warming and Seasonal Precipitation Change Interact to Limit Species Distribution Shifts across Western North America. PLoS ONE 2016, 11, e0159184. [CrossRef] [PubMed]

45. Ordonez, A.; Williams, J.W.; Svenning, J.-C. Mapping Climatic Mechanisms Likely to Favour the Emergence of Novel Communities. Nat. Clim. Chang. 2016, 6, 1104-1109. [CrossRef]

46. Niittynen, P.; Heikkinen, R.K.; Aalto, J.; Guisan, A.; Kemppinen, J.; Luoto, M. Fine-Scale Tundra Vegetation Patterns Are Strongly Related to Winter Thermal Conditions. Nat. Clim. Chang. 2020, 10, 1143-1148. [CrossRef]

47. Mote, P.W.; Li, S.; Lettenmaier, D.P.; Xiao, M.; Engel, R. Dramatic Declines in Snowpack in the Western US. Npj Clim. Atmos. Sci. 2018, 1, 2. [CrossRef]

48. Musselman, K.N.; Addor, N.; Vano, J.A.; Molotch, N.P. Winter Melt Trends Portend Widespread Declines in Snow Water Resources. Nat. Clim. Chang. 2021. [CrossRef]

49. Kittel, T.; White, C.; Hartman, M.; Chowanski, K.; Ackerman, T.; Williams, M.; Losleben, M. Infilled Air Temperature Data for C1 Chart Recorder, 1952-2018, Daily. Environ. Data Initiat. 2019. [CrossRef]

50. Kittel, T.; White, C.; Hartman, M.; Chowanski, K.; Ackerman, T.; Williams, M.; Losleben, M. Infilled Air Temperature Data for D1 Chart Recorder, 1952-2018, Daily. Environ. Data Initiat. 2019. [CrossRef]

51. Bueno de Mesquita, C.P.; Tillmann, L.S.; Bernard, C.D.; Rosemond, K.C.; Molotch, N.P.; Suding, K.N. Topographic Heterogeneity Explains Patterns of Vegetation Response to Climate Change (1972-2008) across a Mountain Landscape, Niwot Ridge, Colorado. Arct. Antarct. Alp. Res. 2018, 50, e1504492. [CrossRef]

52. Sherrod, S.K.; Seastedt, T.R.; Walker, M.D. Northern Pocket Gopher (Thomomys Talpoides) Control of Alpine Plant Community Structure. Arct. Antarct. Alp. Res. 2005, 37, 585-590. [CrossRef]

53. Erb, L.P.; Ray, C.; Guralnick, R. On the Generality of a Climate-Mediated Shift in the Distribution of the American Pika (Ochotona Princeps). Ecology 2011, 92, 1730-1735. [CrossRef]

54. Hofgaard, A.; Løkken, J.O.; Dalen, L.; Hytteborn, H. Comparing Warming and Grazing Effects on Birch Growth in an Alpine Environment-A 10-Year Experiment. Plant Ecol. Divers. 2010, 3, 19-27. [CrossRef]

55. Zhang, T.; Zhang, Y.; Xu, M.; Zhu, J.; Wimberly, M.C.; Yu, G.; Niu, S.; Xi, Y.; Zhang, X.; Wang, J. Light-Intensity Grazing Improves Alpine Meadow Productivity and Adaption to Climate Change on the Tibetan Plateau. Sci. Rep. 2015, 5, 15949. [CrossRef] [PubMed]

56. Ingty, T. Pastoralism in the Highest Peaks: Role of the Traditional Grazing Systems in Maintaining Biodiversity and Ecosystem Function in the Alpine Himalaya. PLoS ONE 2021, 16, e0245221. [CrossRef] [PubMed]

57. Körner, C. Alpine Plant Diversity: A Global Survey and Functional Interpretations. In Arctic and Alpine Biodiversity: Patterns, Causes and Ecosystem Consequences; Ecological, Studies; Chapin, F.S., Körner, C., Eds.; Springer: Berlin/Heidelberg, Germany, 1995; Volume 113, pp. 45-62, ISBN 978-3-642-78968-7. 
58. Taberlet, P.; Zimmermann, N.E.; Englisch, T.; Tribsch, A.; Holderegger, R.; Alvarez, N.; Niklfeld, H.; Coldea, G.; Mirek, Z.; Moilanen, A.; et al. Genetic Diversity in Widespread Species Is Not Congruent with Species Richness in Alpine Plant Communities. Ecol. Lett. 2012, 15, 1439-1448. [CrossRef] [PubMed]

59. Rixen, C.; Wipf, S. Non-equilibrium in Alpine Plant Assemblages: Shifts in Europe's Summit Floras. In High Mountain Conservation in a Changing World; Advances in Global Change, Research; Catalan, J., Ninot, J.M., Aniz, M.M., Eds.; Springer International Publishing: Cham, Switzerland, 2017; Volume 62, pp. 285-303, ISBN 978-3-319-55981-0.

60. Bruun, H.H.; Moen, J.; Virtanen, R.; Grytnes, J.; Oksanen, L.; Angerbjörn, A. Effects of Altitude and Topography on Species Richness of Vascular Plants, Bryophytes and Lichens in Alpine Communities. J. Veg. Sci. 2006, 17, 37-46. [CrossRef]

61. Johnson, P.L.; Billings, W.D. The Alpine Vegetation of the Beartooth Plateau in Relation to Cryopedogenic Processes and Patterns. Ecol. Monogr. 1962, 32, 105-135. [CrossRef]

62. Smithers, B.V.; Oldfather, M.F.; Koontz, M.J.; Bishop, J.; Bishop, C.; Nachlinger, J.; Sheth, S.N. Community Turnover by Composition and Climatic Affinity across Scales in an Alpine System. Am. J. Bot. 2020, 107, 239-249. [CrossRef]

63. Sproull, G.J.; Quigley, M.F.; Sher, A.; González, E. Long-Term Changes in Composition, Diversity and Distribution Patterns in Four Herbaceous Plant Communities along an Elevational Gradient. J. Veg. Sci. 2015, 26, 552-563. [CrossRef]

64. Kazakis, G.; Ghosn, D.; Vogiatzakis, I.N.; Papanastasis, V.P. Vascular Plant Diversity and Climate Change in the Alpine Zone of the Lefka Ori, Crete. Biodivers. Conserv. 2007, 16, 1603-1615. [CrossRef]

65. Clarke, C.L.; Edwards, M.E.; Gielly, L.; Ehrich, D.; Hughes, P.D.M.; Morozova, L.M.; Haflidason, H.; Mangerud, J.; Svendsen, J.I.; Alsos, I.G. Persistence of Arctic-Alpine Flora during 24,000 Years of Environmental Change in the Polar Urals. Sci. Rep. 2019, 9, 19613. [CrossRef]

66. Lamprecht, A.; Semenchuk, P.R.; Steinbauer, K.; Winkler, M.; Pauli, H. Climate Change Leads to Accelerated Transformation of High-Elevation Vegetation in the Central Alps. New Phytol. 2018, 220, 447-459. [CrossRef] [PubMed]

67. Salick, J.; Fang, Z.; Hart, R. Rapid Changes in Eastern Himalayan Alpine Flora with Climate Change. Am. J. Bot. 2019, 106, 520-530. [CrossRef]

68. Spasojevic, M.J.; Bowman, W.D.; Humphries, H.C.; Seastedt, T.R.; Suding, K.N. Changes in Alpine Vegetation over 21 Years: Are Patterns across a Heterogeneous Landscape Consistent with Predictions? Ecosphere 2013, 4, art117. [CrossRef]

69. Huxley, J.D.; Spasojevic, M.J. Area Not Geographic Isolation Mediates Biodiversity Responses of Alpine Refugia to Climate Change. Front. Ecol. Evol. 2021, in press. [CrossRef]

70. Scharnagl, K.; Johnson, D.; Ebert-May, D. Shrub Expansion and Alpine Plant Community Change: 40-Year Record from Niwot Ridge, Colorado. Plant Ecol. Divers. 2019, 12, 407-416. [CrossRef]

71. Pauli, H.; Gottfried, M.; Dullinger, S.; Abdaladze, O.; Akhalkatsi, M.; Alonso, J.L.B.; Coldea, G.; Dick, J.; Erschbamer, B.; Calzado, R.F.; et al. Recent Plant Diversity Changes on Europe's Mountain Summits. Science 2012, 336, 353-355. [CrossRef]

72. Engler, R.; Randin, C.F.; Thuiller, W.; Dullinger, S.; Zimmermann, N.E.; Araújo, M.B.; Pearman, P.B.; Le Lay, G.; Piedallu, C.; Albert, C.H.; et al. 21st Century Climate Change Threatens Mountain Flora Unequally across Europe: CLIMATE CHANGE IMPACTS ON MOUNTAIN FLORAE. Glob. Chang. Biol. 2011, 17, 2330-2341. [CrossRef]

73. Lesica, P.; Crone, E.E. Arctic and Boreal Plant Species Decline at Their Southern Range Limits in the Rocky Mountains. Ecol. Lett. 2017, 20, 166-174. [CrossRef]

74. Compagnoni, A.; Levin, S.; Childs, D.Z.; Harpole, S.; Paniw, M.; Römer, G.; Burns, J.H.; Che-Castaldo, J.; Rüger, N.; Kunstler, G.; et al. Herbaceous Perennial Plants with Short Generation Time Have Stronger Responses to Climate Anomalies than Those with Longer Generation Time. Nat. Commun. 2021, 12, 1824. [CrossRef] [PubMed]

75. Anderson, J.T.; Wadgymar, S.M. Climate Change Disrupts Local Adaptation and Favours Upslope Migration. Ecol. Lett. 2020, 23, 181-192. [CrossRef]

76. Körner, C. The Use of 'Altitude' in Ecological Research. Trends Ecol. Evol. 2007, 22, 569-574. [CrossRef]

77. Elsen, P.R.; Monahan, W.B.; Merenlender, A.M. Topography and Human Pressure in Mountain Ranges Alter Expected Species Responses to Climate Change. Nat. Commun. 2020, 11, 1974. [CrossRef] [PubMed]

78. Williams, J.W.; Jackson, S.T. Novel Climates, No-Analog Communities, and Ecological Surprises. Front. Ecol. Evol. 2007, 5, 475-482. [CrossRef]

79. Inouye, D.W. Effects of Climate Change on Alpine Plants and Their Pollinators. Ann. N. Y. Acad. Sci. 2020, 1469, 26-37. [CrossRef] [PubMed]

80. Dullinger, S.; Gattringer, A.; Thuiller, W.; Moser, D.; Zimmermann, N.E.; Guisan, A.; Willner, W.; Plutzar, C.; Leitner, M.; Mang, T.; et al. Extinction Debt of High-Mountain Plants under Twenty-First-Century Climate Change. Nat. Clim. Chang. 2012, 2, 619-622. [CrossRef]

81. Niskanen, A.K.J.; Niittynen, P.; Aalto, J.; Väre, H.; Luoto, M. Lost at High Latitudes: Arctic and Endemic Plants under Threat as Climate Warms. Divers. Distrib. 2019, 25, 809-821. [CrossRef]

82. Nagy, L.; Grabherr, G. The Biology of Alpine Habitats; The Biology of Habitats Series; Oxford University Press: Oxford, UK; New York, NY, USA, 2009; ISBN 978-0-19-856703-5.

83. Litaor, M.I.; Williams, M.; Seastedt, T.R. Topographic Controls on Snow Distribution, Soil Moisture, and Species Diversity of Herbaceous Alpine Vegetation, Niwot Ridge, Colorado. J. Geophys. Res. 2008, 113, G000419. [CrossRef]

84. Winkler, D.E.; Butz, R.J.; Germino, M.J.; Reinhardt, K.; Kueppers, L.M. Snowmelt Timing Regulates Community Composition, Phenology, and Physiological Performance of Alpine Plants. Front. Plant Sci. 2018, 9, 1140. [CrossRef] 
85. Winkler, D.E.; Chapin, K.J.; Kueppers, L.M. Soil Moisture Mediates Alpine Life Form and Community Productivity Responses to Warming. Ecology 2016, 97, 1553-1563. [CrossRef]

86. Anthelme, F.; Cavieres, L.A.; Dangles, O. Facilitation among Plants in Alpine Environments in the Face of Climate Change. Front. Plant Sci. 2014, 5. [CrossRef]

87. Bowman, W.D.; Murgel, J.; Blett, T.; Porter, E. Nitrogen Critical Loads for Alpine Vegetation and Soils in Rocky Mountain National Park. J. Environ. Manag. 2012, 103, 165-171. [CrossRef]

88. Bowman, W.D.; Theodose, T.A.; Schardt, J.C.; Conant, R.T. Constraints of Nutrient Availability on Primary Production in Two Alpine Tundra Communities. Ecology 1993, 74, 2085-2097. [CrossRef]

89. Yang, Y.; Klein, J.A.; Winkler, D.E.; Peng, A.; Lazarus, B.E.; Germino, M.J.; Suding, K.N.; Smith, J.G.; Kueppers, L.M. Warming of Alpine Tundra Enhances Belowground Production and Shifts Community towards Resource Acquisition Traits. Ecosphere 2020, 11, e03270. [CrossRef]

90. Dong, Z.; Driscoll, C.T.; Johnson, S.L.; Campbell, J.L.; Pourmokhtarian, A.; Stoner, A.M.K.; Hayhoe, K. Projections of Water, Carbon, and Nitrogen Dynamics under Future Climate Change in an Old-Growth Douglas-Fir Forest in the Western Cascade Range Using a Biogeochemical Model. Sci. Total Environ. 2019, 656, 608-624. [CrossRef]

91. Knowles, J.F.; Blanken, P.D.; Lawrence, C.R.; Williams, M.W. Evidence for Non-Steady-State Carbon Emissions from Snow-Scoured Alpine Tundra. Nat. Commun. 2019, 10, 1306. [CrossRef]

92. Morelli, T.L.; Daly, C.; Dobrowski, S.Z.; Dulen, D.M.; Ebersole, J.L.; Jackson, S.T.; Lundquist, J.D.; Millar, C.I.; Maher, S.P.; Monahan, W.B.; et al. Managing Climate Change Refugia for Climate Adaptation. PLoS ONE 2016, 11, e0159909. [CrossRef]

93. Barrows, C.W.; Ramirez, A.R.; Sweet, L.C.; Morelli, T.L.; Millar, C.I.; Frakes, N.; Rodgers, J.; Mahalovich, M.F. Validating Climate-change Refugia: Empirical Bottom-up Approaches to Support Management Actions. Front. Ecol. Environ. 2020, 18, 298-306. [CrossRef]

94. Lawler, J.J.; Ackerly, D.D.; Albano, C.M.; Anderson, M.G.; Dobrowski, S.Z.; Gill, J.L.; Heller, N.E.; Pressey, R.L.; Sanderson, E.W.; Weiss, S.B. The Theory behind, and the Challenges of, Conserving Nature's Stage in a Time of Rapid Change: Conserving Nature's Stage in a Time of Rapid Change. Conserv. Biol. 2015, 29, 618-629. [CrossRef] [PubMed]

95. Engler, R.; Randin, C.F.; Vittoz, P.; Czáka, T.; Beniston, M.; Zimmermann, N.E.; Guisan, A. Predicting Future Distributions of Mountain Plants under Climate Change: Does Dispersal Capacity Matter? Ecography 2009, 32, 34-45. [CrossRef]

96. Saladin, B.; Pellissier, L.; Graham, C.H.; Nobis, M.P.; Salamin, N.; Zimmermann, N.E. Rapid Climate Change Results in Long-Lasting Spatial Homogenization of Phylogenetic Diversity. Nat. Commun. 2020, 11, 4663. [CrossRef]

97. Gao, M.; Piao, S.; Chen, A.; Yang, H.; Liu, Q.; Fu, Y.H.; Janssens, I.A. Divergent Changes in the Elevational Gradient of Vegetation Activities over the Last 30 Years. Nat. Commun. 2019, 10, 2970. [CrossRef]

98. Chapin, F.S.; Walker, L.R.; Fastie, C.L.; Sharman, L.C. Mechanisms of Primary Succession Following Deglaciation at Glacier Bay, Alaska. Ecol. Monogr. 1994, 64, 149-175. [CrossRef]

99. Jurasinski, G.; Kreyling, J. Upward Shift of Alpine Plants Increases Floristic Similarity of Mountain Summits. J. Veg. Sci. 2007, 18, 711-718. [CrossRef]

100. Steinbauer, M.J.; Grytnes, J.-A.; Jurasinski, G.; Kulonen, A.; Lenoir, J.; Pauli, H.; Rixen, C.; Winkler, M.; Bardy-Durchhalter, M.; Barni, E.; et al. Accelerated Increase in Plant Species Richness on Mountain Summits Is Linked to Warming. Nature 2018, 556, 231-234. [CrossRef] [PubMed]

101. Bueno de Mesquita, C.P.; Brigham, L.M.; Sommers, P.; Porazinska, D.L.; Farrer, E.C.; Darcy, J.L.; Suding, K.N.; Schmidt, S.K. Evidence for Phosphorus Limitation in High-Elevation Unvegetated Soils, Niwot Ridge, Colorado. Biogeochemistry 2020, 147, 1-13. [CrossRef]

102. Bueno de Mesquita, C.P.; Sartwell, S.A.; Schmidt, S.K.; Suding, K.N. Growing-season Length and Soil Microbes Influence the Performance of a Generalist Bunchgrass beyond Its Current Range. Ecology 2020. [CrossRef]

103. Kulonen, A.; Imboden, R.A.; Rixen, C.; Maier, S.B.; Wipf, S. Enough Space in a Warmer World? Microhabitat Diversity and Small-Scale Distribution of Alpine Plants on Mountain Summits. Divers. Distrib. 2018, 24, 252-261. [CrossRef]

104. Harsch, M.A.; Hulme, P.E.; McGlone, M.S.; Duncan, R.P. Are Treelines Advancing? A Global Meta-Analysis of Treeline Response to Climate Warming. Ecol. Lett. 2009, 12, 1040-1049. [CrossRef]

105. Capers, R.S.; Stone, A.D. After 33 Years, Trees More Frequent and Shrubs More Abundant in Northeast U.S. Alpine Community. Arct. Antarct. Alp. Res. 2011, 43, 495-502. [CrossRef]

106. Bowling, D.R.; Logan, B.A.; Hufkens, K.; Aubrecht, D.M.; Richardson, A.D.; Burns, S.P.; Anderegg, W.R.L.; Blanken, P.D.; Eiriksson, D.P. Limitations to Winter and Spring Photosynthesis of a Rocky Mountain Subalpine Forest. Agric. For. Meteorol. 2018, 252, 241-255. [CrossRef]

107. Wundram, D.; Pape, R.; Löffler, J. Alpine Soil Temperature Variability at Multiple Scales. Arct. Antarct. Alp. Res. 2010, 42, 117-128. [CrossRef]

108. Garcia, R.A.; Cabeza, M.; Rahbek, C.; Araujo, M.B. Multiple Dimensions of Climate Change and Their Implications for Biodiversity. Science 2014, 344, 1247579. [CrossRef] [PubMed]

109. Seddon, A.W.R.; Macias-Fauria, M.; Long, P.R.; Benz, D.; Willis, K.J. Sensitivity of Global Terrestrial Ecosystems to Climate Variability. Nature 2016, 531, 229-232. [CrossRef] [PubMed]

110. Laiolo, P.; Dondero, F.; Ciliento, E.; Rolando, A. Consequences of Pastoral Abandonment for the Structure and Diversity of the Alpine Avifauna. J. Appl. Ecol. 2004, 41, 294-304. [CrossRef] 
111. Benedict, J.B. Rates of Tree-Island Migration, Colorado Rocky Mountains, USA. Ecology 1984, 65, 820-823. [CrossRef]

112. Fitzpatrick, O.T.; Blade, M.; Fishback, L.A.; Kershaw, G.P.; Muffly, J.; Mamet, S.D. Snowpack, Tree Size, and Ecological Legacies Promote Seedling Establishment in Tree Islands at the Treeline. Ecosystems 2020, 23, 1714-1725. [CrossRef]

113. Jabis, M.D.; Germino, M.J.; Kueppers, L.M. Colonisation of the Alpine Tundra by Trees: Alpine Neighbours Assist Late-Seral but Not Early-Seral Conifer Seedlings. Plant Ecol. Divers. 2020, 13, 209-224. [CrossRef]

114. Wilson, S.D.; Nilsson, C. Arctic Alpine Vegetation Change over 20 Years. Glob. Chang. Biol. 2009, 15, 1676-1684. [CrossRef]

115. Fazlioglu, F.; Wan, J.S.H. Warming Matters: Alpine Plant Responses to Experimental Warming. Clim. Chang. 2021, 164, 56. [CrossRef]

116. Jin, Y.; Xu, J.; He, H.; Li, M.-H.; Tao, Y.; Zhang, Y.; Hu, R.; Gao, X.; Bai, Y.; Wang, H.; et al. The Changbai Alpine Shrub Tundra Will Be Replaced by Herbaceous Tundra under Global Climate Change. Plants 2019, 8, 370. [CrossRef]

117. Wheeler, J.A.; Hoch, G.; Cortés, A.J.; Sedlacek, J.; Wipf, S.; Rixen, C. Increased Spring Freezing Vulnerability for Alpine Shrubs under Early Snowmelt. Oecologia 2014, 175, 219-229. [CrossRef] [PubMed]

118. Lu, X.; Liang, E.; Wang, Y.; Babst, F.; Camarero, J.J. Mountain Treelines Climb Slowly despite Rapid Climate Warming. Glob. Ecol. Biogeogr. 2021, 30, 305-315. [CrossRef]

119. Hansson, A.; Dargusch, P.; Shulmeister, J. A Review of Modern Treeline Migration, the Factors Controlling It and the Implications for Carbon Storage. J. Mt. Sci. 2021, 18, 291-306. [CrossRef]

120. Dobrowski, S.Z.; Parks, S.A. Climate Change Velocity Underestimates Climate Change Exposure in Mountainous Regions. Nat. Commun. 2016, 7, 12349. [CrossRef]

121. Andrus, R.A.; Harvey, B.J.; Rodman, K.C.; Hart, S.J.; Veblen, T.T. Moisture Availability Limits Subalpine Tree Establishment. Ecology 2018, 99, 567-575. [CrossRef]

122. Hufft, R.A.; DePrenger-Levin, M.E.; Levy, R.A.; Islam, M.B. Using Herbarium Specimens to Select Indicator Species for Climate Change Monitoring. Biodivers. Conserv. 2018, 27, 1487-1501. [CrossRef] 